\title{
PELATIHAN DASAR PROGRAM STATISTICAL PRODUCT \\ AND SERVICE SOLUTIONS (SPSS) BAGI MAHASISWA \\ SEMESTER 6 (ENAM) FAKULTAS ILMU BUDAYA \\ UNIVERSITAS LANCANG KUNING
}

\section{OLEH :}

1. Yuhelmi, S. Kom, M. Kom (Ketua)

2. Rosman, H., M. Hum (Anggota)

3. Fiqru mafar, M.IP (Anggota)

\begin{abstract}
ABSTRAK
Pada hakekatnya mahasiswa yang akan menyusun tugas akhir biasanya sedikit agak bingung pada saat materi kuliah sudah habis , pada umumnya mereka bingung tentang masalah yang akan mereka angkat karena sebahagian besar belum memiliki pengalaman dan belum pernah melakukan penelitian serta belum tahu program yang dipakai untuk mengolah data, mungkin ada juga yang sudah tahu tapi memanfaatkannya belum bisa untuk itu maka kami selaku tim Dosen FIB Unilak tertarik untuk melakukan pengabdian masyarakat mengingat masih banyak mahasiswa yang kebingungan dalam hal mengolah data penelitiannya, sehingga kami tertarik untuk mengangkat judul pengabdian ini yakni "Pelatihan dasar program SPSS bagi mahasiswa semester 6 (Enam) Fakultas Ilmu Budaya Universitas Lancang Kuning”, karena kalau data tersebut diolah dengan manual akan sangat lama apalagi kalau sampai ratusan data yang akan diolah makanya pelatihan ini sangat tepat dilakukan sehingga mereka nantinya dapat menyelesaikan tugas akhir tepat waktu dengan bantuan program SPSS. Dari hasil kegiatan yang telah dilakukan bahwa terlihat peserta antusias dalam mengikuti pelatihan, ini terbukti dengan banyaknya pertanyaan dan tanggapan mereka setelah instruktur menyampaikan materi dan memberikan pratikum langsung, mereka menaruh minat yang sangat tinggi terhadap teknologi komputer serta meminta agar ada kelanjutan dari pelatihan ini.
\end{abstract}

\begin{abstract}
In essence the student will prepare the final project is usually a little bit confused at the time of the course material is up, they are generally confused about the issues that will be adopted because they are by and large do not have the experience and have never done the research and do not know which program is used to process the data, there may well already know but have not been able to use it then we as a team of lecturers FIB Unilak interested in doing community service since there are many students who are confused in terms of data processing research, so we were keen to lift the title this devotion that is "basic training program SPSS for students of 6th semester (six) Faculty of Humanities University of Lancang Kuning ", because if the data is processed by manual will be very long especially if hundreds of data to be processed so it is
\end{abstract}


appropriate training so that they can complete the final task on time with the help of SPSS program. From the results of the activities that have been done that looks enthusiastic participant in training, is evidenced by the many questions and their responses after the instructors delivering the material and give pratikum directly, they put a very high interest towards computer technology and requested that no continuation of this training.

\section{Key word : Statistical Product And Service Solutions}

\section{PENDAHULUAN}

\subsection{Latar Belakang}

Komputer adalah alat yang sangat luar biasa berguna untuk mempermudah dan mempercepat perhitungan dan analisa data. Namun seperti alat-alat yang lain, program analisa data based on computer bisa saja mengalami kesalahan penggunaan. Jika kita salah memasukan data atau menggunakan prosedur analisis yang kurang tepat, maka hasilnya pun tidak akan berarti apa-apa, tidak membantu, bahkan akan menyesatkan kita. Perhatikan peraturan pertama dari komputer: "Sampah yang masuk, sampah pula yang yang keluar" (Garbage in, garbage out). Ingat, jika kita salah dalam memilih prosedur analisis, hasilnya tidak akan berarti apa-apa.

Tak bisa dibantah jika kita mengolah data statistik dengan komputer maka yang pertama kali terbayang adalah SPSS. SPSS memang salah satu program statistik yang paling populer di antara program lainnya. SPSS banyak digunakan dalam penelitian-penelitian sosial dan riset, yang sesuai dengan kepanjangan SPSS yaitu: Statistical Package for the Social Science. Walaupun sekarang singkatannya menjadi Statistical Product and Service Solution (karena fungsinya yang lebih berkembang) namun tetap saja SPSS lebih sering digunakan dalam penelitian sosial. Banyak persoalan, apakah itu hasil penelitian, riset ataupun pengamatan, baik yang dilakukan khusus ataupun berbentuk laporan, dinyatakan dan dicatat dalam bentuk bilangan atau angka-angka.

Apabila pengolahan dilakukan tanpa menggunakan SPSS pun data-data tersebut dapat diolah akan tetapi sesuai dengan perkembangan Ilmu Pengetahuan dan Teknologi Informasi yang sangat cepat berkembang sekarang ini rasanya amat fatal dan kata orang sangat aneh kalau data-data yang jumlahnya tidak sedikit itu diolah secara manual, jadi mau tidak mau kita selaku generasi penerus 
bangsa harus bisa mengikuti perkembangan teknolgi tersebut, salah satunya adalah memanfaatkan software pengolah data, yang akan kami berikan pelatihan tersebut kepada mahasiswa Fakultas Ilmu Budaya semester 6 (enam).

Dari temuan kami dilapangan masih banyak mahasiswa Fakultas Ilmu Budaya tersebut yang belum mengerti dan belum bisa menggunakan SPSS tersebut dalam mengolah data-data mereka untuk menyelesaikan tugas akhir apabila tugas akhir itu mengunakan data-data yang harus diolah, sehingga banyak yang menggunakan jasa seseorang untuk membuatkan olahan data tersebut karena mereka tidak faham dan tidak mengerti menggunakan SPSS maupun program pengolah data lainnya.

Hal ini disebabkan oleh beberapa anggapan mahasiswa :

1. Bahwa untuk mulai belajar SPSS harus Kursus dahulu yang tentunya perlu dana ekstra .

2. Belum meratanya kemampuan mahasiswa dalam hal pengolahan data

3. Belum mengetahui cara menginstal program tersebut pada Laptopnya, apalagi untuk menggunakannya masih banyak yang bingung.
4. Tidak dipelajari khusus pada bangku perkuliahan.

Disamping itu kami dari tim pengabdian merasa terpanggil untuk dapat melaksanakan pengabdian masyarakat ini karena merasa bertanggung jawab atas keberhasilan mahasiswa kita dalam pendidikan dengan pemanfaatan teknologi komputer ini, yang akhirnya dapat dipergunakan dalam penyusunan tugas akhir, dan juga yang akan dibawa nantinya dalam dunia kerja.

Sekali lagi kami dari tim pengabdian dilapangan menemukan masih banyak mahasiswa yang bingung dalam mengolah data dengan SPSS, sehingga sampai saat ini masih belum menemukan solusi yang tepat untuk mengatasi masalah tersebut.

Dari Kondisi seperti ini maka kami ingin mengadakan pengabdian masyarakat sebagai bagian dari Tri Darma Perguruan Tinggi melalui “ Pelatihan Dasar Program SPSS bagi Mahasiswa Semester 6 (enam) Fakultas Ilmu Budaya, Pelatihan ini sangat penting untuk meningkatan kemampuan mahasiswa dalam mengolah data saat akan menyelesaikan tugas akhir.

\subsection{Rumusan Masalah}


Dari latar belakang yang telah diuraikan didepan dapat dirumuskan masalah dan diidentifikasi sebagai berkut :

1. Bagaimana Pengetahuan Mahasiswa Semester enam (6) FIB tentang pengolahan data dengan SPSS untuk penyusunan tugas akhir?

2. Bagaimana menginstall Program SPSS pada laptop atau perangkat keras yang mereka miliki?.

3. Bagaimana Pelatihan SPSS dapat memotivasi mahasiswa semester enam (6) FIB tersebut dalam menyusun tugas akhir?.

\section{TINJAUAN PUSTAKA}

Kata statistik berasal dari bahasa latin (Status) yang berarti Negara atau hal-hal yang berhubungan dengan ketatanegaraan. Oleh karena itu Aima (2006) menyatakan bahwa pada mulanya kata statistik diartikan sebagai keterangan-keterangan yang dibutuhkan oleh negara dan berguna bagi negara. Lambat laun kata statistik diartikan sebagai data kuantitatif dan data kualitatif, baik yang belum tersusun maupun yang sudah tersusun dalam tabel.
Sujana (1996), kumpulan angkaangka ini sering disusun, diatur atau disajikan dalam bentuk daftar atau tabel. Sering pula daftar atau tabel tersebut disertai dengan gambar-gambar yang biasa disebut diagram atau grafik supaya lebih dapat menjelaskan lagi tentang persoalan yang sedang dipelajari.

Penggunaan statistika pada masa sekarang dapat dikatakan telah menyentuh semua bidang ilmu pengetahuan mulai dari astronomi hingga linguistika. Bidang-bidang ekonomi , biologi dan cabang cabang terapannya, serta psikologi banyak dipengaruhi oleh statistika dalam metodologinya. Akibatnya lahirlah ilmu-ilmu gabungan seperti ekonometrika, biometrika atau biostatistika dan psikometrika. Dari hasil pengamatan atau sering diminta atau diinginkan suatu uraian, penjelasan atau kesimpulan tentang persoalan yang diteliti.

\section{Statistik Deskriptif}

Adalah bagian dari ilmu statistika untuk menganalisis data dengan cara mendiskripsikan atau mengambarkan data yang telah terkumpul sebagaimana adanya tanpa bermaksud membuat kesimpulan yang berlaku untuk umum/generalisasi. Dengan kata lain hanya melihat gambaran secara umum dari data yang didapatkan. 
Santoso (2006) menjelaskan bahwa statistik deskiptif berusaha menjelaskan dan mengambarkan berbagai karakteristik data, seperti berapa rata-ratanya, seberapa jauh data bervariasi dari rata-ratanya, berapa median data dan sebagainya.

Hasan (2004) menjelaskan, analisa deskriptif adalah merupakan bentuk analisis data penelitian untuk menguji generalisasi hasil penelitian berdasarkan satu sampel.

\section{Statistik Induktif}

- Djarwanto dan Subagyo (1996) menyatakan statistik Induktif atau inferensial adalah bidang ilmu pengetahuan statistik yang mempelajari tata cara penarikan kesimpulan mengenai keseluruhan populasi berdasarkan data yang ada dalam suatu bagian dari populasi tersebut (disebut sampel).

- Didalamnya berisi tentang estimasi, pengujian hipotesis, melakukan prediksi observasi masa depan atau membuat model regresi dan perhitungan derajat asosiasi antara variabel-variabel.

- Dalam suatu analisis data penelitian umumnya ada 4 macam problematik yang umumnya muncul sebagai landasan dalam analisis data, yaitu :

1. Problem untuk mengetahui status dan mendiskripsikan fenomena

2. Problem Komperasi, yaitu problem yang bertujuan untuk membandingkan dua fenomena atau lebih.

3. Problem untuk mencari hubungan antara dua fenomena yang kedudukannya sejajar (bukan sebab akibat).

4. Problem untuk melihat pengaruh sesuatu perlakuan atau ingin melihat hubungan antara variabel bebas dan terikat.

Sebelum masuk pada tahap demi tahap SPSS, pengetahuan tentang jenis-jenis data dalam statistik adalah syarat utama yang harus dikuasai. Pengetahuan tentang jenis-jenis data sangat menentukan metode yang akan digunakan dalam pengambilan data dan tentu saja jenis analisis apa yang dibutuhkan oleh data tersebut agar lebih bermakna.

Menurut Iqbal (2004) dalam Sayid syekh (2011) data adalah bentuk jamak dari datum. Data merupakan keteranganketerangan tentang suatu hal, dapat berupa sesuatu yang diketahui atau yang 
dianggab atau anggapan. Atau suatu fakta yang digambarkan lewat angka, symbol, kode dan lain-lain.

Jadi data adalah sesuatu yang diketahui atau sesuatu yang dianggab memberikan gambaran suatu masalah.

Jenis-Jenis Data Statistik

A. Menurut sifatnya :

a. Data Kualitatif, yaitu data yang tidak berbentuk angka, misal berupa sifat, kualitas atau kondisi. Skala pengukuran Nominal atau ordinal

- Misal : Prestasi siswa sangat meningkat, Penyaluran dana bos sangat lancar, biaya sekolah sangat mahal.

b. Data Kuantitatif, yaitu dalam bentuk angka. Skala pengukuran Interval atau Rasio

- Misalnya : Rata-rata nilai matematika siswa 80, Biaya SPP perbulan Rp. 100.000, Sebanyak 99\% siswa dinyatakan tamat dan lulus.

B. Menurut Sumbernya :

1. Data Internal yaitu data yang menggambarkan keadaan/ kegiatan didalam suatu organisasi.

Dalam suatu perguruan tinggi misalnya data dosen, data keuangan, data karyawan, data mahasiswa, dsb.

2. Data Eksternal yaitu data yang menggambar kan keadaan/ kegiatan diluar suatu organisasi.

Bagi suatu perguruan tinggi misal nya tingkat daya beli masyarakat, perkembangan biaya produksi, permintaan dsb.

C. Menurut cara memperolehnya

1. Data Primer yaitu data yang dikumpulkan dan diolah sendiri oleh organisasi atau perseorangan langsung dari objeknya. Misalnya Depag RI melakukan pendataan siswa yang akan memperoleh beasiswa

2. Data sekunder yaitu data yang diperoleh dalam bentuk yang sudah jadi, sudah dikumpulkan dan diolah oleh pihak lain, biasanya sudah dalam bentuk publikasi.

D. Menurut waktu pengumpulannya

1. Cross-section Data, yaitu data yang dikumpulkan pada suatu 
waktu tertentu (at a point time)

yang bisa menggambarkan

keadaan/ kegiatan pada waktu

tsb. Misal suatu sekolah yang

mengumpulkan data anak usia

sekolah disekitar sekolah pada tahun tertentu.

2. Time series data, data yang dikumpulkan dari waktu ke waktuuntuk memberikan gambaran tentang perkembang an suatu kegiatan. Misal banyak pendaftar pada suatu sekolah tertentu selama 10 tahun terakhir

E. Menurut tempat pengumpulannya

1. Perpustakaan yaitu data yang diperoleh berdasarkan studi kepustakaan di perpustakaan

2. Laboratorium yaitu data yang diperoleh melalui laboratorium, biasanya menu pakan data hasil penelitian

3. Lapangan yaitu data yang dikumpulkan langsung di lapangan, biasanya merupakan hasil observasi

F. Menurut tingkatan pengukurannya, penulis biasa menyingkatnya dengan "NOIR" atau"RION". Jenis data tersebut adalah:

\section{Data Rasio}

Data rasio adalah tingkatan data yang paling tinggi. Data rasio memiliki jarak antar nilai yang pasti dan memiliki nilai nol mutlak yang tidak dimiliki oleh jenis-jenis data lainnya. Contoh dari data rasio diantaranya: berat badan, panjang benda, jumlah satuan benda. Jika kita memiliki 10 bola maka ada perwujudan 10 bola itu, dan ketika ada seseorang memiliki 0 bola maka seseorang tersebut tidak memiliki bola satu pun. Data rasio dapat digunakan dalam komputasi matematik, misalnya A memiliki 10 bola dan B memiliki 8 bola, maka A memiliki 2 bola (10-8) lebih banyak dari B.

\section{Data Interval}

Data interval mempunyai tingkatan lebih rendah dari data rasio. Data interval memiliki jarak data yang pasti namun tidak memiliki nilai nol mutlak. Contoh dari data interval ialah hasil dari nilai ujian matematika. Jika si A mendapat nilai 10 dan si B mendapat nilai 8, maka dipastikan si A mempunyai 2 nilai 
lebih banyak dari B. Namun tidak ada nilai nol mutlak, maksudnya bila $\mathrm{C}$ mendapat nilai 0 , tidak berarti bahwa kemampuan $\mathrm{C}$ dalam pelajaran matematika adalah nol atau kosong.

\section{Data Ordinal}

Data ordinal pada dasarnya adalah hasil dari kuantifikasi data kualitatif. Contoh dari data ordinal yaitu penskalaan sikap individu. Penskalaan sikap individu terhadap sesuatu bisa diwujudkan dalam bermacam bentuk, diantaranya yaitu: dari sikap Sangat Setuju (5), Setuju (4), Netral (3), Tidak Setuju (2), dan Sangat Tidak Setuju (1). Pada tingkatan ordinal ini data yang ada tidak mempunyai jarak data yang pasti , misalnya: Sangat Setuju (5) dan Setuju (4) tidak diketahui pasti jarak antar nilainya karena jarak antara Sangat Setuju (5) dan Setuju (4) bukan 1 satuan (5-4).

\section{Data Nominal}

Data nominal adalah tingkatan data paling rendah menurut tingkat pengukurannya. Data nominal ini pada satu individu tidak mempunyai variasi sama sekali, jadi 1 individu hanya punya 1 bentuk data. Contoh data nominal diantaranya yaitu: jenis kelamin, tempat tinggal, tahun lahir dll. Setiap individu hanya akan mempunyai 1 data jenis kelamin, laki-laki atau perempuan. Data jenis kelamin ini nantinya akan diberi label dalam pengolahannya,misalnya

perempuan $=1$, laki-laki $=2$.

Ada lagi jenis data yang sering disebutkan dalam statistik yaitu data parametric dan nonparametric. Jika "NOIR" adalah pembagian data menurut tingkatan pengukuran, pembagian parametric dan non-parametric dipengaruhi oleh karakteristik empirik dari data tersebut. Pengetahuan tentang batasan data parametric dan non-parametric ini sangat penting karena pada proses analisis memang dibedakan untuk masing-masing jenis data tersebut.

\section{TUJUAN DAN MANFAAT KEGIATAN}

Pelatihan ini bertujuan untuk membekali mahasiswa : 
1. Mempersiapkan diri untuk Dalam melaksanakan metode ini penyusunan skripsi.

2. Meningkatkan kemampuan Mahasiswa dalam menggunakan Program SPSS serta dapat menginstal program SPSS pada komputer sendiri.

3. Memberikan motivasi dan kesempatan kepada Mahasiswa Fakultas Ilmu Budaya bahwa menyusun skripsi yang menggunakan pengolahan data dengan SPSS tidaklah sesulit yang dibayangkan.

Akhirnya dengan adanya pelatihan ini diharapkan mahasiswa Fakultas Ilmu Budaya yang akan menyusun skripsi dapat memanfaatkan SPSS dan dapat menambah wawasan para peserta dalam menggunakan komputer khususnya program SPSS serta memudahkan peserta dalam mengolah data-datanya dan dapat meningkatkan rasa percaya diri dalam bersaing dengan mahasiswa lain dari Universitas yang berbeda.

\section{METODE PELAKSANAAN}

Metode yang akan kita gunakan dalam pelatihan ini adalah :

- Ceramah dan Penyuluhan

penceramah atau penyuluh menyampaikan materi dan Penyuluhan kepada para peserta tersebut.

- Diskusi

Dalam sesi ini para peserta pelatihan diberi kesempatan untuk berdiskusi dengan sesama peserta dan penceramah bertindak sebagai fasilitatornya lalu akan diberikan juga kesempatan untuk bertanya kepada para peserta oleh penceramah.

- Workshop

Pada kegiatan workshop ini para peserta akan diberikan praktek langsung secara bersamaan dilokasi pelatihan.

- Sharing atau berbagi ilmu pengetahuan

Saat praktek peserta dapat saling berbagi pengetahuannya.

\section{RANCANGAN EVALUASI}

Evaluasi dilaksanakan setelah selesai kegiatan pemberian materi dan praktek di Laboratorium Komputer, kemudian untuk melihat feedbacknya digunakan metode pemberian kuisioner yang harus diisi peserta, dari hasil 
kuisioner tersebut akan diketahui bagaimana pemahaman peserta terhadap materi yang diberikan selama pelatihan berlangsung.

Untuk mengetahui pemahaman mereka dapat dilihat dari pernyataan yang telah dijawab melalui angket yang telah disebarkan kepada peserta dengan analisa data tabel dan deskriptif sebagai berikut :

Tabel 1. Tanggapan tentang pelatihan dasar Program SPSS

\begin{tabular}{|l|l|l|c|}
\hline No. & $\begin{array}{c}\text { Alternatif } \\
\text { Jawaban }\end{array}$ & Frekuensi & Persentase \\
\hline 1. & Perlu & 24 & $92,31 \%$ \\
\hline 2. & Tidak Perlu & 2 & $7,69 \%$ \\
\hline \multicolumn{2}{|c|}{ Jumlah } & 26 & $100 \%$ \\
\hline
\end{tabular}

Dari tabel diatas dapat diketahui bahwa sebanyak 24 orang atau 92,31\% peserta memilih bahwa kegiatan ini perlu dilakukan dalam rangka meningkatkatkan kemampuan mahasiswa dalam mengolah data untuk penyusunan tugas akhir.

Untuk item pertanyaan apakah pelatihan ini sesuai dengan perkembangan saat ini? Dari angket yang diolah bahwa hampir seluruh peserta menjawab sesuai karena kalau kita tidak mampu mengolah data tugas akhir dengan cepat dan akurat akan menyebabkan keterlambatan dalam pelaporannya nanti. Selanjutnya untuk item pertanyaan harapan mereka untuk pelatihan berikutnya dari hasil kuesioner terlihat sebagian besar 23 orang mengharapkan agar pelatihan selanjutnya lebih menekankan pada uji hipotesis dan uji reabilitas serta uji validitas, selanjutnya hasil olahan kuesioner ini juga diberikan kepada Kajur (Ketua Jurusan) Ilmu Perpustakaan yang telah mengirim mereka untuk ikut pelatihan tersebut.

\section{HASIL DAN PEMBAHASAN}

\subsection{HASIL}

Kegiatan ini dilaksanakan di Ruang Laboratorium Komputer Universitas Lancang Kuning pada tanggal 11 Juni 2013. Dari kegiatan yang telah dilaksanakan, beberapa hasil telah diperoleh. Pada tahap pertama, Instruktur menjelaskan teori serta pengertian SPSS serta menjelaskan proses penginstallan pada perangkat komputer serta laptop sehingga peserta memperoleh pemahaman tentang konsep dasar program SPSS.

Pelatihan ini dapat meningkatkan kemampuan para mahasiswa tersebut dalam menggunakan program SPSS untuk pengolahan data dengan komputer. 
Karena pada tahap kedua, peserta diajak untuk praktik dengan menggunakan komputer langsung, setiap satu komputer hanya untuk satu peserta, mereka dapat melakukan penginstallan sendiri dengan software program SPSS pada perangkat serta laptop mereka. Sehingga para peserta dapat mengaplikasikan teori yang telah disampaikan.

Pada tahap terakhir, setelah peserta memiliki ketrampilan dalam menggunakan komputer untuk pengolahan data penelitian serta bagaiman memindahkan data yang sudah ada pada program Ms. Excel ke Program SPSS dengan cepat tanpa harus mengetik ulang dan diberi pelatihan bagaimana melakukan uji validasi dan reabilitas serta uji hipotesis, melakukan regresi linier sederhana serta apa yang ddapat disimpulkan dari hasil pengolahan data tersebut.

\subsection{PEMBAHASAN}

Kegiatan ini langkah dan pratiknya antara lain:

1. Ceramah tentang bagaimana menginstall program SPSS ver. 17 pada perangkat, membuat perhitungan dengan SPSS. Pada tahap ini peserta mengikuti dan menyerap konsep dasar program SPSS sehingga dapat melakukan pengolahan data nantinya saat pembuatan skripsi serta paham melakukan uji validaasi dan reabilitas serta juga uji hipotesis. Kesemua itu akhirnya harus tetap dipergunakan dalam kegiatan sehari-hari dalam mengelola data, karena kalau tidak semua ilmu yang telah diberikan akan hilang Jadi semua peserta dituntut bisa mengaplikasikan semua materi yang sudah disampaikan.

2. Setelah peserta memahami dasar dasar program SPSS, pada tahap ini peserta diminta bagi yang udah paham untuk dapat memberitahukan kepada peserta lain yang belum begitu mengerti tentang materi yang telah dibahas.

3. Sesi berikutnya adalah sesi praktik menjalankan dan menggunakan Program SPSS dan dilanjutkan dengan sharing sesama peserta lainnya.

4. Sesi terakhir adalah sesi tanya jawab. Pada sesi ini peserta diberikan kesempatan untuk 
menanyakan dan menanggapi mengenai teori yang telah dipaparkan sebelumnya. Peserta terlihat antusias untuk menanyakan hal-hal yang berkaitan dengan tema pelatihan. Menurut mereka hal ini merupakan sesuatu yang menarik, terutama mengenai kegiatan praktik langsung didepan komputer, satu peserta satu komputer. Pertanyaan yang menarik adalah mengenai apakah semua kegiatan yang telah dipelajari dapat diwujudkan di fakultas, karena pada umumnya akan terbentur masalah pendanaan. Kegiatan pengembangan penggunaan komputer untuk pengolahan data dapat dilakukan dengan melakukan program bekerjasama pemerintah daerah melalui bantuan pengadaan komputer di Fakultas yang memadai atau mandiri untuk membuat Labor yang lebih representatif serta dengan jumlah perangkat yang mencukupi.

5. Dalam praktiknya, suatu pelatihan tidak akan berjalan lancar jika tidak dibarengi dengan kemauan pada masingmasing peserta. Untuk itu, peserta diberi keyakinan bahwa hasil yang memuaskan tidak akan muncul begitu saja dengan mudah, tetapi diperlukan konsistensi dan keyakinan bahwa sesederhana apapun kegiatan yang dilakukan jika diikuti dengan keyakinan yang kuat maka akan memberikan hasil yang memuaskan.

\section{KESIMPULAN DAN SARAN}

\subsection{KESIMPULAN}

Pelatihan dasar program SPSS ini membekali para mahasiswa :

1. Dalam mengolah data dengan cepat, tepat dan akurat.

2. Pelatihan ini dapat memotivasi mereka agar tidak bingung lagi saat akan menyusun tugas akhir, pelatihan ini tidak akan berarti apa-apa bila tidak ada tindak lanjutnya dari peserta untuk mempergunakan dan memanfaatkan materi dan hasil yang telah diperoleh. 
3. Kegiatan ini sangat tepat dilakukan guna mendukung mahasiswa yang akan melakukan penulisan tugas akhir agar mereka dapat terbantu dalam hal mengolah data.

\subsection{SARAN}

Setelah pelatihan ini dilaksanakan diharapkan peserta :

1. Dapat membagi ilmunya kepada para mahasiswa lainnya agar setiap ilmu yang kita peroleh menjadi ladang amal bagi kita semua yaitu ilmu yang bermanfaat.

2. Setiap peserta dapat memanfaatkan ilmu yang sudah diperoleh dalam menunjang hasil skripsi yang lebih bermutu, mudahmudahan ada kelanjutan dari pelatihan ini. Sebagai salah satu kegiatan pendukung peningkatan kualitas pendidikan karena dengan makin meningkatnya kualitas penelitian yang dilakukan oleh mahasiswa akan menghasilkan lulusan fakultas Ilmu Budaya yang berkualitas pula sehingga nantinya dapat bersaing dengan fakultas lain yang akhirnya dapat bersaing pula dengan Universitas lain,

3. Jadi pelatihan saja tidak cukup tanpa adanya kemauan untuk merealisasikan ilmu yang telah didapatkan. Hal ini harus tumbuh dari dalam diri mahasiswa itu sendiri agar tetap menggunakan ilmu yang telah diperoleh dari pelatihan ini yang nantinya akan membantu mereka dalam mengolah data-data tugas akhir.

\section{DAFTAR PUSTAKA}

Aima Havis. 2006. Statistik, Penerbit Candra Pratama Jakarta.

Djarwanto dan Pangestu Subagyo. 1996. Statistik Induktif, Edisi Keempat, Yogyakarta:BPFE

Elcom. 2011.Belajar Kilat SPSS 17, Andipublisher

Hasan, I. 2004. Statistik Deskriptif. http//id.wikipedia.org/wiki/S tatistika_deskriptif.

Santoso, S.2006. Menguasai Statistik di era Informasi dengan SPSS 14. 
Jakarta:PT Elex Media

Komputindo.

Santoso, Singgih. 2004.Latihan SPSS

Statistik Multivariat,Jakarta :

Elex Media Komputindo.

Sudjana. 1996. Metode Statististika.

Edisi ke 6.

Bandung:"Tarsito"

Syekh, Sayid. 2011. Pengantar Statistik

Ekonomi Dan Sosial.Gaung

Persada Press Jakarta.

Teguh Handoyo. 2009. 25 Model Analisis Statistik dengan SPSS 17.Elex Media Komputindo. 